


\title{
Dephosphorylation of tyrosine phosphorylated synthetic peptides by rat liver phosphotyrosine protein phosphatase isoenzymes
}

\author{
Massimo Stefani ${ }^{\mathrm{a}}$, Anna Caselli ${ }^{\mathrm{b}}$, Monica Bucciantini ${ }^{\mathrm{b}}$, Luigia Pazzaglib, Fabrizio Dolfi ${ }^{\mathrm{b}}$, Guido Camici ${ }^{\mathrm{b}}$, \\ Giampaolo Manao ${ }^{\mathrm{b}}$ and Giampietro Ramponi ${ }^{\mathrm{b}}$
}

${ }^{a}$ Department of Molecular Biology, University of Siena, Siena, Italy and ${ }^{\mathrm{b}}$ Department of Biochemical Sciences, University of Florence, Florence, Italy

Received 13 May 1993

\begin{abstract}
Five phosphotyrosine-containing peptides have been synthesized by FMOC solid-phase peptide synthesis. These peptides correspond to the $411-419$ sequence of the Xenopus src oncogene, to the 1191-1220 sequence of the human EGF receptor precursor, to the 1146-1158 sequence of the human insulin receptor, to the 856-865 sequence of the human $\beta$-PDGF receptor, and to the 5-16 sequence of the erythrocyte human band 3 . The peptides were used as substrates for activity assay of two isoforms (AcP1 and AcP2) of a low molecular weight cytosolic PTPase. The assay, performed in microtiter EIA plates using Malachite green to determine the released phosphate, was rapid, reproducible, and sensitive. Both PTPase isoforms were able to hydrolyze all synthesized peptides, though with different affinity and rate. The main kinetic parameters were compared and discussed with respect to the role of the two enzymes in the cell.
\end{abstract}

Phosphopeptide; Phosphotyrosine protein phosphatase; PTPase; Protein phosphatase; Phosphotyrosine

\section{INTRODUCTION}

A low $M_{\mathrm{r}}$ phosphotyrosine protein phosphatase (E.C. 3.1.3.48) is present in the cytosol of a number of tissues [1]. (The enzyme was previously referred to as low $M_{\mathrm{r}}$ acid phosphatase (E.C. 3.1.3.2.)) This enzyme is active toward Tyr-phosphorylated protein substrates [2-4] although it also catalyzes the hydrolysis of low $M_{\mathrm{r}}$ compounds such as $p$-nitrophenylphosphate ( $p$ NPP), L-phosphotyrosine, and acylphosphates [5-7].

The mechanism of the enzymatic reaction of the bovine heart enzyme has recently been identified, demonstrating the formation of a cysteinylphosphate co-

Correspondence address: G. Ramponi, Department of Biochemical Sciences, Viale Morgagni 50, 50100 Florence, Italy. Fax: (55) (39) 422 2725.

Abbreviations: EGF, epidermal growth factor; EIA, enzyme immunoassay; FMOC, fluoren-9-ylmethoxycarbonyl-; RP, reverse-phase; OPfp, pentafluorophenyl ester; HOBt, hydroxybenzotriazole; BOC, $t$-butoxycarbonyl-; DMF, dimethylformamide; DIPCDI, diisopropylcarbodiimide; $\mathrm{TMSBr}$, trimethylbromosilane; TFA, trifluoroacetic acid; FAB, fast atom bombardment; AcP1, rat liver low molecular weight PTPase isoform 1; AcP2, rat liver low molecular weight PTPase isoform 2; PTyr, phosphotyrosine; $\operatorname{srcl} \mathrm{P}_{\mathrm{i}}$, phosphorylated peptide corresponding to the 411-419 sequence of the Xenopus src oncogene product; EGFRP $P_{i}$, phosphorylated peptide corresponding to the 1192-1200 sequence of the human EGF receptor precursor; IRP, Tyrl150-phosphorylated peptide corresponding to the 1146-1158 sequence of the human insulin receptor; PDGFR $\mathrm{P}_{2} 2$, phosphorylated peptide corresponding to the 856-865 sequence of the human $\beta$-PDGF receptor; $\mathrm{B} 3 \mathrm{P}_{\mathrm{i}}$, phosphorylated peptide corresponding to the 5-16 sequence of the human erythrocyte anion channel (band 3). valent intermediate during catalysis [8]. The formation of a thiolphosphate intermediate appears as a specific event in the reaction mechanism of all PTPase family members [9-11]. Other phosphatases, such as acid and alkaline phosphatases form different covalent intermediates during the catalytic process [12]. The active site of this PTPase contains the sequence motif C-X-X-X-X$X-R$ in the $12-18$ zone (both Cys and Arg are essential for the activity) and thus resembles the active site motif of the classical PTPase family members [13].

The enzyme from bovine liver has been sequenced in our laboratory [14]. It consists of a single polypeptide chain of 157 amino acid residues among which are present 8 cysteines, all in the reduced form [14]; two of these cysteine residues are involved in the catalytic site [1315]. In other tissues, two isoenzymes differing only in the sequence of the 40-73 region are present [16]; they probably arise from alternative splicing.

The enzyme has been expressed in $E$. coli using a synthetic polydeoxyribonucleotide with a sequence derived from that of the enzyme from bovine liver [17].

Recently, an experiment concerning the overexpression of the low $M_{\mathrm{r}}$ PTPase in v-erb-B transformed fibroblasts [18] seemed to confirm the role of this enzyme as a possible regulatory element of cell growth [19].

By looking for biologically relevant substrates which could be dephosphorylated by this enzyme, it was observed that the autophosphorylated EGF receptor was efficiently dephosphorylated in vitro [3]. On the other hand, this search for possible physiological substrates for this enzyme, as well as for other PTPases, is hin- 
dered by the substantial difficulty of providing suitable substrates, since tyrosine phosphorylation occurs at very low levels within cells and the phosphoproteins are difficult to isolate and purify. Moreover, this makes the assay of the activity of these enzymes on substrates biologically more significant than synthetic phosphate esters such as $p$-nitrophenylphosphate, or L-phosphotyrosine not easy.

$O$-Phosphonotyrosyl peptide synthesis can help to overcome these difficulties by providing phosphopeptides the sequence of which can be derived from that of the phosphorylation site of any phosphotyrosine protein kinase target protein the sequence of which is known. These peptides can therefore be considered as useful tools for routinely measuring the activity of PTPases and for preliminary investigations on their substrate specificity, if it exists.

Methods have recently been reported of the use of phosphotyrosyl peptides in PTPase activity tests [20,21]; these methods allow rapid, sensitive, reproducible, and accurate activity measurements that do not require the use of ${ }^{32} \mathrm{P}$. In particular, a Malachite green colorimetric assay for phosphoserine protein phosphatase activity has recently been reported [21]. We extended this method to the phosphotyrosine protein phosphatase activity assay, and improved it in order to make the phosphatase assay easier and quicker by performing the reaction in microtiter EIA plate wells in the presence of varying phosphotyrosine-containing peptides which have previously been synthesized.

We used the above method to check the behavior of five phosphopeptides (derived from the sequence near the phosphorylation sites of the src gene product, the EGF receptor, the insulin receptor, the $\beta$-PDGF receptor, and the human erythrocyte band 3 ) as substrates of the low $M_{\mathrm{r}}$ phosphotyrosyl protein phosphatase isoforms from rat liver ( $\mathrm{AcP} 1$ and $\mathrm{AcP} 2)$.

\section{MATERIALS AND METHODS}

FMOC-Tyr $\left(\mathrm{PO}_{3} \mathrm{Me}_{2}\right) \mathrm{OH}$ was from Bachem, all other amino acid derivatives, DMF, piperidine, diisopropylcarbodiimide, and TFA were from MilliGen, as well as FMOC-Val-PepSynKA, FMOC-GlnPepSynKA, and FMOC-Leu-PepSynKA resins. The CI8 RP HiPore column was from Bio-Rad. The DEAE-HPLC column was from LKB. Membranes for automatic peptide sequencing were from MilliGen. All other reagents and solvents were of the highest available purity. The peptide sequences were taken from the PC-Gene data bank.

\subsection{Phosphopeptide synthesis}

Tyr(P)-containing peptides were prepared using a MilliGen PepSynthesizer by FMOC/solid-phase synthesis through dimethylphosphate protection using a Kieselguhr-polydimethylacrylamide resin functionalized with $\beta$-alanine as internal reference amino acid, the acid labile 4-hydroxymethylphenoxyacetic acid linkage agent, and containing the FMOC-protected COOH-terminal residue. Subsequent peptide bond forming reactions utilized a fourfold excess of the OPfp-ester of the appropriate FMOC-amino acid (Dhbt-ester in the case of Ser and Thr) (4 equiv.) in the presence of 1 equiv, of $\mathrm{HOBt}$. FMOCTyr $\left(\mathrm{PO}_{3} \mathrm{Me}_{2}\right)$ -
OH was coupled in the presence of DIPCDI/HOBt. Side chain protection was carried out with $t$-butyl ester and ether for Asp, Glu, Ser, Thr, and Tyr, with the BOC group for Lys, and with the Mtr group for Arg. FMOC group deprotection was carried out with $20 \%$ piperidine in DMF. All other synthesis steps were carried out in DMF.

At completion of the synthesis, the resin-bound peptide was cleaved from the resin and deprotected with $1 \mathrm{M}$ TMSBr-thioanisole/TFA ( $m$-cresol, $10 \mathrm{mEquiv}$. Tyr) at $4^{\circ} \mathrm{C}$ for times varying from 8 to $15 \mathrm{~h}$, depending upon each peptide. The crude peptide was either low pressure evaporated, precipited and washed with cold diethyl ether or directly treated with it. The peptide was then purified by semipreparative C18 RP-HPLC which, in the case of src1P, was preceded by DEAE-HPLC.

\subsection{Peptide purity assessment}

The peptide purity was determined by amino acid analysis, FABmass spectrometry, and amino acid sequencing. Amino acid analysis was carried out as previously described [22]. Values for serine and threonine were corrected for loss during hydrolysis. The amino acid sequence was determined by Edman degradation by using a MilliGen Protein Sequencer mod. 6600 on peptides covalently immobilized on polyvinylidene difluoride membranes derivatized with 1,4-phenylene diisothiocyanate (Sequelon DITC) or arylamine groups (Sequelon AA). Owing to its particular amino acid sequence, B3P $P_{i}$ was sequenced manually by Edman degradation. FAB mass spectra were determined using a VG Analytical 70-70 EQ instrument as previously described [23]. The peptide concentration was determined on the basis of the amino acid content. Phosphate analysis in the synthesized peptides was performed on a peptide sample of known concentration by the method of Fiske and Subbarow [24].

\subsection{PTPase purification}

The two isoforms of the low molecular weight PTPase, indicated by $\mathrm{AcP} 1$ and $\mathrm{AcP} 2$, were purified from rat liver as previously described [16].

\section{RESULTS AND DISCUSSION}

The synthesis and deprotection method used allowed us to obtain pure phosphotyrosine-containing peptides, even though extensive purification of the crude peptides was necessary, probably owing to the presence of impurities arising mainly from the deprotection step, which uses trimethylbromosilane as a hard acid source. For this reason we found that, in order to obtain crude peptides with minor impurities, the time of deprotection was critical and different for the varying synthesized phosphopeptides. The purified peptides were checked for purity by amino acid analysis, FAB mass spectrometry, amino acid sequencing, and inorganic phosphate determination by both combustion and enzymic hydrolysis. The correct amino acid composition was obtained

Table I

Sequence of the synthesized phosphopeptides

\begin{tabular}{ll} 
SrclP $_{\mathrm{i}}$ & $\mathrm{H}_{2}$ N-E-D-N-E-YP-T-A-R-Q-COOH \\
EGFRP $_{\mathrm{i}}$ & $\mathrm{H}_{2}$ N-A-E-N-A-E-YP-L-R-V-COOH \\
IRP $_{\mathrm{i}}$ & $\mathrm{H}_{2}$ N-Y-E-T-D-YP-Y-R-K-G-G-K-G-L-COOH \\
PDGFRP $2^{2}$ & $\mathrm{H}_{2}$ N-N-YP-I-S-K-G-S-T-F-L-COOH \\
B3P $_{\mathrm{i}}$ & $\mathrm{H}_{2}$ N-Q-D-D-YP-E-D-M-M-E-E-N-L-COOH \\
\hline
\end{tabular}

$Y P=$ Phosphotyrosine 


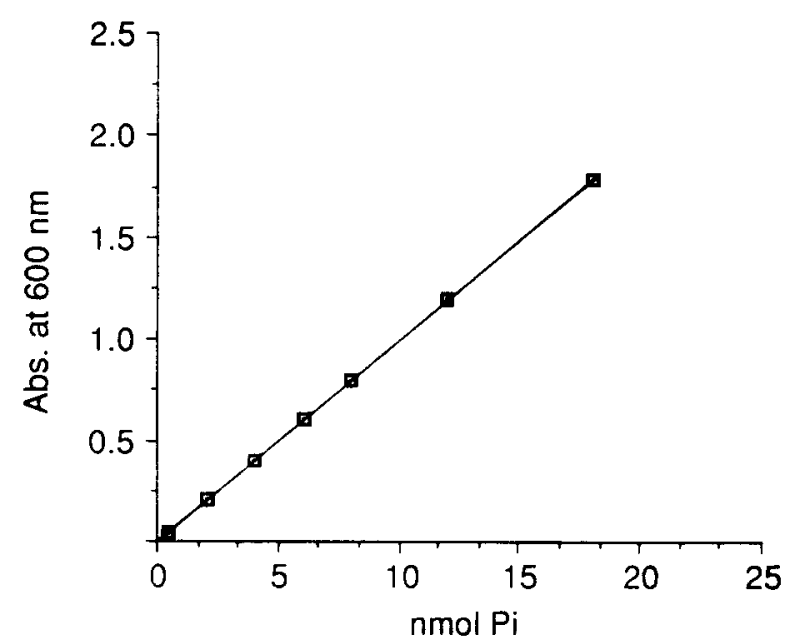

Fig. 1. Standard curve for phosphate determination by the Malachite green assay. Each point was the average of four determinations.

for each peptide (the hydrolysis product, Tyr, was observed for PTyr). The amino acid sequence data for each phosphopeptide were consistent with the expected sequence (Table I). The inorganic phosphate determination in both ways showed a phosphate/peptide molar ratio of about 1 .

The positive FAB mass spectra of the target peptides contained a distinct molecular ion at $\mathrm{m} / \mathrm{z}$ values one unit higher with respect to the calculated molecular weight of each peptide, corresponding to the $\mathrm{M}+\mathrm{H}^{+}$species.

The PTPase activity of the two purified enzymes (AcP1 and AcP2) was determined by a Malachite green test. $400 \mathrm{ml}$ of $0.1 \mathrm{M}$ acetate buffer, pH 5.5, containing $1 \mathrm{mM}$ EDTA and varying concentrations of each phosphopeptide were incubated at $37^{\circ} \mathrm{C}$ for $20 \mathrm{~min}$ in the presence of $5 \mathrm{U} / \mathrm{ml}$ of either AcPl or AcP2. The reaction was stopped by adding $100 \mathrm{ml}$ of the staining solution previously described $[20,24]$ and left standing for $10 \mathrm{~min}$ at room temperature. The mixture was then centrifuged, $400 \mathrm{ml}$ of the supernatant transferred in wells of microtiter EIA plates and the absorbance at 600 $\mathrm{nm}$ measured. The amount of inorganic phosphate released was determined by comparison with a standard curve prepared together with the experiments using an inorganic phosphate standard solution.

Fig. 1 shows the standard curve of the phosphate determination. As can be seen, the limit of sensitivity of this test is about $0.5 \mathrm{nmol}$ of phosphate. The test was highly reproducible, with minor differences among absorbance values relative to different experiments.

Using this assay procedure, we have been able to determine the main kinetic parameters of AcPl and $\mathrm{AcP} 2$ relative to the synthesized phosphotyrosine containing peptides as well as to either PNPP and free phosphotyrosine. Table II reports the kinetic data of the two enzyme isoforms. It can be noted that the two enzymes show $\mathrm{pH}$ optimum values in the $4.5-5.5$ range on

phosphotyrosine and PNPP, as well as on all phosphorylated peptides, except $\mathrm{B}_{3} \mathrm{P}_{\mathrm{i}}$, on which they elicit a $\mathrm{pH}$ optimum in the 4.0-5.0 range, probably due to the sharp acidic nature of this peptide. This further confirms a positive regulation of the enzyme activity by the $\mathrm{H}^{+}$ion. As for affinity for the varying substrates tested and catalytic rate of their hydrolysis by the two enzymes, it can be pointed out that the apparent $K_{\mathrm{m}}$ values of the two enzymes for the phosphorylated peptides, as well as for phosphotyrosine and PNPP, are very similar and in the $0.2-0.6 \mathrm{mM}$ range, except for the apparent $K_{\mathrm{m}}$ value of AcP2 for L-phosphotyrosine, which is one order of magnitude higher. Exceptions are represented by the low affinity values of both enzymes for PDGFRP $_{\mathrm{i}} 2$ as well as of $\mathrm{AcP} 1$ for $\mathrm{B}^{3} \mathrm{P}_{\mathrm{i}}$. The low affinity of $\mathrm{AcPl}$ and $\mathrm{AcP} 2$ for $\mathrm{PDGFRP}_{\mathrm{i}} 2$ could be due to the fact that, differently from the other peptides, the phosphotyrosine residue is located near the N-terminus in this peptide; this could render the positioning of the phosphotyrosine residue into the active site more difficult. The absence of a free $\alpha$-amino group near the phosphotyrosine residue of the other peptides could be the cause of the lowering of the apparent $K_{\mathrm{m}}$ values to levels similar to those of PNPP (Table I). AcP1 shows a low affinity also for $\mathrm{B}^{3} \mathrm{P}_{\mathrm{i}}$; in this case, the high apparent $K_{\mathrm{m}}$ value could tentatively be ascribed to the acidic

Table II

Main kinetic parameters of $\mathrm{AcP} 1$ and AcP2 for varying phosphorylated substrates

\begin{tabular}{lll}
\hline AcP1 & AcP2 \\
\hline
\end{tabular}

$K_{\mathrm{m}}(\mathrm{mM})$

\begin{tabular}{|c|c|c|}
\hline PNPP & 0.3 & 0.3 \\
\hline P-Tyr & 0.6 & 6.0 \\
\hline $\operatorname{srclP}_{i}$ & 0.2 & 0.2 \\
\hline $\operatorname{IrP}_{\mathrm{i}}$ & 0.4 & 0.6 \\
\hline EGFRP $_{i}$ & 0.7 & 0.6 \\
\hline PDGFRP $_{i} 2$ & 3.0 & 2.0 \\
\hline $\mathrm{B} \mathrm{P}_{\mathrm{i}}$ & 1.4 & 0.4 \\
\hline
\end{tabular}

$V_{\max }\left(\mu \mathrm{mol} \cdot \mathrm{min}^{-1} \cdot \mathrm{mg}^{-1}\right.$

$\begin{array}{lrr} & & \\ \text { PNPP } & 99.0 & 69.8 \\ \text { P-Tyr } & 86.1 & 48.1 \\ \text { srclP }_{i} & 3.7 & 2.8 \\ \text { IrP }_{i} & 3.1 & 4.6 \\ \text { EGFRP }_{i} & 8.0 & 3.7 \\ \text { PDGFRP }_{i} & 107.7 & 9.6 \\ \text { B3P }_{i} & 68.0 & 10.5\end{array}$

pH optimum

\begin{tabular}{lll} 
PNPP & $4.5-5.5$ & $4.5-5.5$ \\
P-Tyr $_{\text {srclP }_{i}}$ & $4.9-5.9$ & $4.6-5.4$ \\
IRP $_{\mathrm{i}}$ & $4.5-5.5$ & $4.5-5.5$ \\
EGFRP $_{\mathrm{i}}$ & $5.0-5.5$ & $5.0-5.5$ \\
PDGFRP $_{\mathrm{i}}$ & $4.5-5.5$ & $4.5-5.5$ \\
B3P $_{\mathrm{i}}$ & $5.0-5.5$ & $5.0-5.5$ \\
\hline
\end{tabular}


nature of $\mathrm{B} 3 \mathrm{P}_{\mathrm{i}}$, which is strongly negative at $\mathrm{pH}$ values near the $\mathrm{pH}$ optimum, lacking any basic residue.

The different affinities of AcP1 and AcP2 for both free phosphotyrosine and $\mathrm{B}_{3} \mathrm{P}_{\mathrm{i}}$ probably reside in peculiar differences in the sequence 40-73, the only segment which is different in the two enzymes. On the other hand, the $K_{\mathrm{m}}$ values of each enzyme for the different tested substrates suggest that there is a variability in phosphopeptide substrate affinity, src1P showing the highest affinity and hence, probably, the best fitting into the substrate binding site.

PDGFRP $_{\mathrm{i}} 2$ and $\mathrm{B}_{3} \mathrm{P}_{\mathrm{i}}$ are the most efficiently hydrolyzed peptides, and in this case it can be pointed out that AcP1 shows a higher hydrolysis rate with respect to AcP2. The PDGFRP $P_{i}$ and $\mathrm{B}^{2} \mathrm{P}_{\mathrm{i}}$ hydrolysis rate by $\mathrm{AcPl}$ is very high, almost two orders of magnitude higher than that of the other peptides and the same order of magnitude as that of PNPP and free phosphotyrosine; the hydrolysis rate of the two peptides by $\mathrm{AcP} 2$ is quite lower, though higher than that of any other tested peptide. This observation is noteworthy, indicating that PDGFRP $_{\mathrm{i}} 2$ and $\mathrm{B}_{3} \mathrm{P}_{\mathrm{i}}$ are good peptide substrates for AcP1 and, to a lesser extent, for AcP2, and suggests that the catalytic efficiency and affinity of the two enzymes on the purified, tyrosinephosphorylated proteins should be checked. These data also support the hypothesis, arising from the different amino acid sequences in the $40-73$ region, that the two enzymes elicit some differences in the catalytic sites and have different cellular target substrates. Furthermore, these findings, together with those relative to the different behavior of AcP1 and AcP2 towards inhibitors and activators [15], suggest that the two isoenzymes, which are expressed at the same time in different tissues [26], perform different physiological functions. We think that the use of synthetic peptides containing phosphotyrosine and the availability of a suitable method to measure their dephosphorylation rate (like the one described in this paper) are useful for screening among synthetic substrates in the search for the physiological phosphorylated protein substrates for every specific PTPase.

Acknowledgements: This work was supported in part by the Consiglio Nazionale delle Ricerche, target project on Peptidi bioattivi and in part by the Ministero della Università e della Ricerca Scientifica e Tecnologica $(60 \%)$. The peptide synthesizer was achieved through a grant from the Consorzio Interuniversitario di Biotecnologie. The authors thank the Centro di Spettrometria di Massa of the Medical School of the University of Florence for FAB mass spectrometry analyses.

\section{REFERENCES}

[1] Aranjo, P.S., Mies, V. and Miranda, O. (1976) Biochim. Biophys. Acta 452, 121-130.

[2] Chernoff, J. and Lee, H.C. (1985) Arch. Biochem. Biophys. 240, $135-145$.

[3] Ramponi, G., Manao, G., Camici, G., Cappugi, G., Ruggiero, M. and Bottaro, D.P. (1989) FEBS Lett. 250, 469-473.

[4] Zhang, Z.Y. and Van Etten, R.L. (1990) Arch. Biochem. Biophys. $282,39-49$.

[5] Heinrikson, R.L. (1969) J. Biol. Chem. 244, 299-307.

[6] Lawrence, G.L. and Van Etten, R.L. (1981) Arch. Biochem. Biophys. 206, 122-131.

[7] Ramponi, G., Cappugi, G., Manao, G. and Camici, G. (1980) Proceedings of the 26th National Congress of the Società Italiana di Biochimica, Bologna, September 24-26, p. 167.

[8] Wo, Y.Y.P., Zhou, M.M., Stevis, P., Davis, J.P., Zhang, Z.Y. and Van Etten, R.L. (1992) Biochemistry 31, 1712-1721.

[9] Pot, D.A. and Dixon, J.E. (1992) Biochim. Biophys. Acta 1136, $35-43$.

[10] Cho, H., Krishnaraj, R., Kitas, E., Bannwarth, W., Walsh, C.T and Anderson, K.S. (1992) J. Am. Chem. Soc. 114, 7296-7298.

[11] Guan, K.L. and Dixon, J.E. (1991) J. Biol. Chem. 266, 1702617030.

[12] Vincent, J.B., Crowder, M.W. and Averill, B.A. (1992) Trends Biochem. Sci. 17, 105-110.

[13] Cirri, P., Chiarugi, P., Camici, G., Manao, G., Raugei, G., Cappugi, G. and Ramponi, G. (1993) Eur. J. Biochem., in press.

[14] Camici, G., Manao, G., Cappugi, G., Modesti, A., Stefani, M. and Ramponi, G. (1989) J. Biol. Chem. 264, 2560-2567.

[15] Chiarugi, P., Marzocchini, R., Raugei, G., Pazzagli, C., Berti, A., Camici, G., Manao, G., Cappugi, G. and Ramponi, G. (1992) FEBS Lett. 310, 9-12.

[16] Manao, G., Pazzagli, L., Cirri, P., Caselli, A., Camici, G., Cappugi, G., Saeed, A. and Ramponi, G. (1992) J. Prot. Chem. 11, 333-345.

[17] Raugei, G., Marzocchini, R., Modesti, A., Ratti, G., Cappugi, G., Camici, G., Manao, G. and Ramponi, G. (1991) Biochem. Int. 23, 317-326.

[18] Ramponi, G., Ruggiero, M., Raugei, G., Berti, A., Modesti, A Degl'Innocenti, D., Magnelli, L., Pazzagli, C., Chiarugi, P. and Camici, G. (1992) Int. J. Cancer 51, 652-656.

[19] Hunter, T. (1989) Cell 58, 1013-1016.

[20] Madden, J.A., Bird, M.I., Man, Y., Raven, T. and Myles, D.D (1991) Anal. Biochem. 199, 210-215.

[21] Geladopoulos, T.P., Sotiroudis, T.G. and Evangelopoulos, A.E. (1991) Anal. Biochem. 192, 112-116.

[22] Manao, G., Camici, G., Cappugi, G., Stefani, M., Liguri, G., Berti, A. and Ramponi, G. (1985) Arch. Biochem. Biophys. 241, 418-424.

[23] Camici, G., Manao, G., Cappugi, G., Berti, A., Stefani, M., Liguri, G. and Ramponi, G. (1983) Eur. J. Biochem. 137, 269277.

[24] Fiske, H. and Subbarow, Y. (1925) J. Biol. Chem. 66, 375

[25] Baykov, A.A., Evtushenko, O.A. and Avaeva, S.M. (1988) Anal Biochem. 171, 266-270.

[26] Fujimoto, S., Murakami, R., Ishikawa, A., Himi, K. and Ohara, A. (1988) Chem. Farm. Bull. 36, 3020-3026. 